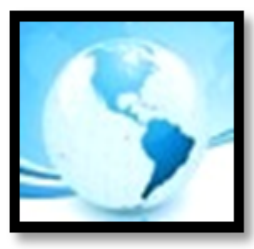

MALAYSIAN ONLINE JOURNAL OF

EDUCATIONAL MANAGEMENT

(MOJEM)

October 2019, VOLUME 7, ISSUE 4, 45-63

E-ISSN NO: $2289-4489$

\title{
COMMITMENT, WORK ENGAGEMENT, AND RESEARCH PERFORMANCE OF LECTURERS, IN INDONESIA PRIVATE UNIVERSITIES
}

Alex Winarno ${ }^{1} \&$ Deni Hermana ${ }^{2}$

[1] Telkom University, Bandung, Indonesia

[2] Universitas Pakuan, Bogor, Indonesia

Corresponding Author:

E-mail: alexwinarno70@gmail.com

\begin{abstract}
The purpose of the study was to identify the effect of commitment, work engagement on research performance of the lecturers in Private Universities. The research method used was an explanatory survey. Data processing was performed statistically using Structural Equation Modeling. The respondents of this study are lecturers of Private Universities in West Java and Banten Province, Indonesia. The total sample chosen at random was 388 lecturers. The results of the study show that the implementation of the Human Resources (HR) function to improve research performance of the lecturers is based on JDR (job demand resources). The good performance of research, community service and teaching are based on the work paradigm. The orientation of private universities HR function to optimize performance has not touched the commitment aspect as much as an effort to encourage work engagement and improve lecturer performance. Performance is influenced by work engagement based on commitment based on ethical awareness of the function of lecturers in higher education. Efforts to meet job demand and job resources are physical, psychologically, and ethically in the work function to improve the performance that is managed as a sustainable system.
\end{abstract}

Keywords: Commitment, Performance, Work Engagement, Lecturers, Private Universities, Indonesia. 


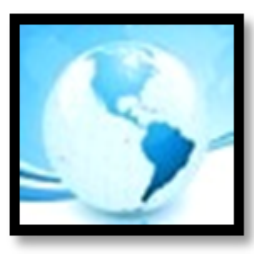

\section{INTRODUCTION}

Demands on the role of higher education in the fourth industrial revolution is getting more dynamic and heavier, especially for developing countries. Efforts to encourage the increasing human capital is carried out by encouraging the development and improvement of knowledge through research. Lecturers act as one of the drivers in increasing the ability of higher education institutions for carrying out their roles. This is in accordance with Law No. 14 of 2005 on Teachers and Lecturers, stating that as a professional educator and scientist with the main task of transforming, developing and disseminating science, technology, and art through education, research, and community service.

The Government of the Republic of Indonesia, through the Ministry of Research, Technology and Higher Education, continues to encourage and facilitate lecturers to always improve their performance. This support is realized in the form of various regulatory instruments, namely: (1) Law number 20 of 2003 concerning the national education system; (2) Law number 14 of 2005 concerning teachers and lecturers; (3) Government regulation number 60 of 1999 concerning higher education; (4) Government regulation number 61 of 1999 concerning tertiary institutions as a state-owned legal entity (BHMN); (5) Government regulation number 19 of 2005 concerning national education standards; (6) Government regulation number 37 of 2009 concerning lecturers; (7) Government regulation number 41 of 2009 concerning professional allowances for teachers and lecturers, special allowances for teachers and lecturers, and honorary benefits for professors; (8) Minister of Education Regulation number 47 of 2009 concerning educator certification for lecturers; (9) Regulation of Menkowasbangpan (Coordinating Ministry), number 38 of 1999 concerning functional positions of lecturers and their credit score; and (10) Guidelines for Lecturer Workload and Evaluation of the Implementation of Higher Education Tridarma Director General of Higher Education 2010. One regulation the Government of the Republic of Indonesia referred to as above is Law No. 14 of 2005 Article 45. It states that lecturers must have academic qualifications, competence, certification of educators, physical and spiritual health as well as meet the other qualifications required units of higher education places on duty and have the ability to achieve national education goals.

Among the three main tasks of the lecturers; namely education and teaching, research, and community service, the performance of the research field is the least as expected. Based on the data published by the Ministry of Research and Technology of Higher Education in 2016, the performance of the faculty's research is still low. The number of publications in reputable international journals, which is one of the indicators of the performance of the research faculty across colleges and research institutions shows that Indonesia is still lower than the ASEAN countries.

Pa'wan and Omar (2018) state that the dynamics of the universities' environment in a highly competitive global era. Ahmad (2014) stated that higher education institutions are expected to be able to face the challenges of the globalization era. Adewale, Ghavifekr, and Megat Daud (2018) showed the strategic role of education for sustainable development. Ghasemy, Hussin, Daud, and Nor (2015) showed the significant contribution of higher institutions to society. Khalid (2016) asserts that higher education is one of the economic sub-sectors. Nedeva, Boden, and Nugroho (2012) added that higher education is a complex organization and that the community judges the quality of higher education based on its output. Variation of higher education output mainly come from teaching services and research (Khalid, 2016).

There are various obstacles in terms of efforts to improve the role and function of higher education as a catalyst for science. Ghavifekr, Afshari, Siraj, Zabidi, and Razak (2013) explained that educational institutions experienced many changes. The success of realizing organizational performance is influenced by organizational performance systems with a focus on morale and loyalty (Al-Sinawi et al., 2016). There have been various explanations regarding individual performance including in the world of education and lecturers are a part of it. Research, teaching and community service are mostly interpreted as epistemology. The interaction between lecturers and their world is 


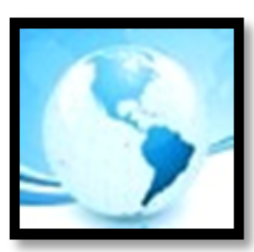

\section{MALAYSIAN ONLINE JOURNAL OF EDUCATIONAL MANAGEMENT (MOJEM)}

closed. This makes the performance of lecturers to be seen only as an obligation. The lecturers are seldom carried away in their work as agents of science that encourage emancipation, especially in relation to the worldview. In addition to its contribution through the provision of human resources, universities also have a role in the form of research work to solve the problems that occur in society and the nation. Deem, Hillyard, and Reed (2007) stated that a paradigm shift in higher education governance is a keyword in the management of higher education. The paradigm shift is translated into more sustainable performance management.

One of the performances demanded by lecturers is research. Lecturers need support to realize their functions as stated by Lucki and Yusoff (2013) in order to improve their performance. Chen (2015) describes research as a priority and on the other hand the reward system is very low. Wood (1990) stated the factors that influence the performance of research in higher education are: individual characteristics of organizational members consisting of differences in ability, energy, creativity, motivation, ambition and self-discipline. The need for affiliation (Rakhmatullin \& Brennan, 2013). Participatory decision making and academic rankings affect the performance of lecturers (Sukirno \& Siengthai, 2011). Ganieva, Sayfutdinova, Yunusova, Sadovaya, and Neile (2015) state that lecturers are required to increase their competency. In terms of motivation, according to Rasmussen (2016), productivity of lecturers' research is influenced by many factors including motivation (Edgar \& Geare, 2013), reward systems (Pfeffer \& Langton, 1993), commitment and intrinsic motivation (Cerasoli, Nicklin, \& Ford, 2014). Fitzmaurice (2013) states that the basis actions of a lecturer who is active in research, namely value, virtue, individual trust, joy, satisfaction in conducting research. Nguyen (2015) suggested HR management capacity as the main approach to improve university research performance. A combination of didactic skills, professional practice, and research competence (Griffioen, 2018). Functions of lecturer performance are characteristics or personal traits possessed.

Job demand resources provide an explanation of how performance is reviewed personally, systemically and environmentally. Baloyi et al. (2014) described the performance management system as a holistic system. Then, Bakker and Demerouti (2018) suggested work engagement as a positive mental condition. Identifying the lecturers' research performance in private universities is somewhat complex. This shows a variety of dynamic conditions that determine the performance of lecturers. An explanation of the performance of lecturers is needed to formulate a framework in solving the problem of weak performance of lecturers, especially in research.

Performance are considered as transaction value between individual and organization. Human resource function in advocating the development of lecturers' performances in higher education field. Lecturers' research performance cannot be separated from the fact that human is a social creature who always seeks for information in their lives. Unfortunately, research performances are sometimes being undermined as self-manifestation to improve self's dialectical level. Research performances is a manifestation of awareness, curiosity, and better understanding about the truth through interactive dialogues with data sources and science community. Goldman (1999) stated that seeking information is a common activity in human lives. This means that lecturers are required to present in the epistemological dynamic sides of science community. Furthermore, Moser (2002: 22) added that moral epistemology related to "how do we justify knowledge and belief" are rarely discussed in the current field.

The issue that lacks attention is the problem of knowledge agents. The lecturers who conduct research are too focused on knowledge and justification but never talk about knowledge agents. Traditional epistemology for acquiring knowledge is less followed by demands on knowledge agents. The epistemological dominant positivism and subjectivism which becomes mainstream stumbles upon the idea of moral objectivity. Loughlin (2004) argues for the need to overcome the epistemological foundation by considering questions in the epistemology and philosophy of science. The challenges of lecturers are not only on epistemology objects but how the axiology of science is obtained through research.

The position of the lecturer as part of the education authority determines how the flow of information is included for practical reasons. Research is a process of social interaction that shows the universal features of human 


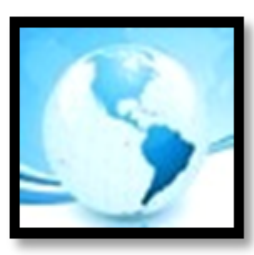

\section{MALAYSIAN ONLINE JOURNAL OF EDUCATIONAL MANAGEMENT (MOJEM)}

communication and the prototype of truth-seeking practices (Goldman, 1999). The significance of lecturer performance for the development of private universities are not in doubt and can be seen in the University's reputation and economic condition Blackburn et al. (1995). Okoro (2013) assessed the importance of science generated through lecturer research, patent registration (Hedjazi \& Behravan, 2011). Research can be used as a framework for building metamodel about the performance of lecturers in the field of research based on Job Demand Resources theory on the reasoning process, better explanation, evidence, and axioms of research variable validity. Gigch (1996) explains that there are dilemmas among conflicting imperatives that arise in management situations, actions that are "useful" economically and technically but which, at the same time, must satisfy the aesthetic, ethical and legal requirements needed.

The research objective was to identify the effect of commitment, and work engagement on research performance of lecturers in Indonesian Private Universities. The research objective is specifically to get an explanation on the effect of: (1) Lecturers' commitment on their research performance directly, (2) Lecturers' commitment on their work engagement directly, and (3) Lecturers' work engagement on their research performance directly.

\section{LITERATURE REVIEW}

\section{Organisational Commitment}

Commitment is the attitude of employees to remain in the organization and be involved in efforts to achieve the mission, values and goals in the company. This commitment factor is considered important because employees who have a high commitment to the organization will tend to have a professional attitude and uphold the agreed values. Meyer and Allen (1993) argue that commitment as a psychological state that either characterizes the employee's relationship with the organization or has the implications to affect whether the employee will continue with the organization. Based on this definition members who are committed to their organization will be more able to survive as part of the organization than members who are not committed to the organization. Ulrich (1998) included in intellectual capital is commitment. Poff (2001) explains commitment is affective interest in a behaviour, as stated: Commitment has also been defined as the pledging or binding of an individual to behavioural actions which results in some degree of affective attachment to the behaviour or the role associated with the behaviour and which produce side batch as a result of that behaviour. Firat, Mul, and Wichelen (2009, p.7) provides a limitation that commitment has an association with intellectuals, as stated: "Redefining commitment as a practice rather than being enables us to expand the subject of commitment from the singular to diverse social agents such as institutions, organizations, movements, disciplines, and cultural products". Robbins and Judge (2017) identify that commitment is the level at which an employee in favour of a particular organization and goals and intend to maintain membership in the organization. Employees are willing to sacrifice for the organization if they are committed enough. According to studies by Meyer and Allen (1993) alongside Kumar and Eng (2012), commitments are divided into 3 dimensions, namely affective commitment, continuance commitment, and normative commitment.

\section{Work Engagement}

Work engagement refers to persistent and pervasive cognitive-affective states that are not only focused on a particular object, event, individual, or behaviour but also on general conditions in work. Kahn (1990) defines work engagement as an employee's effort to carry out work duties and responsibilities by using self-expression, cognitive and emotional. Ghorbannejad and Esakhani (2016) suggested that employee engagement and work engagement share same characteristic and forming aspects. Work engagement is a condition where a person has a positive mind, he is able to express himself both physically, cognitively and affective in doing his work (Schaufeli \& Bakker, 2004). Job involvement is a condition that is related to work that is positive, satisfying, motivationalaffective welfare (Leiter \& Bakker, 2010). Bakker and Demerouti (2018) states the majority of studies adopting an approach between individuals showed that there were differences in the level of average work engagement 


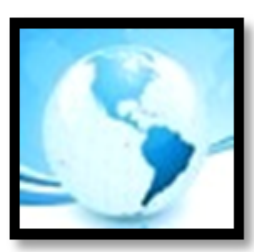

\section{MALAYSIAN ONLINE JOURNAL OF EDUCATIONAL MANAGEMENT (MOJEM)}

between individuals as a function of work conditions, personal characteristics, and behavioural strategies. Knowledge of work engagement from an individual perspective is considered insufficient to explain work engagement in work life and organization. Bakker and Demerouti (2018) describes work engagement as a positive, fulfilling, and related mental state of mind about work characterized by enthusiasm, dedication, and absorption. In the study by Bakker, Demerouti, and Sanz-vergel (2014), work engagement is characterized by high energy and strong identification with work. Work engagement is characterized by an awareness of the meaning of work where people feel they have energy, enthusiasm, high mental endurance while working, have dedication and enthusiasm, concentration and dissolve in the work.

\section{Performance}

Performance is often interpreted by work achievement. Sihotang (2016) argues that performance involves a number of dimensions, namely: (1) Persona, this dimension describe work as values of human being. Work is selfexpression, a totality of self as a person, total work involvement, (2) Working, it involves other people in work, a picture of awareness towards others through work, (3) Working is a fair behavioural depiction as a manifestation of morality awareness and responsibility towards the usefulness of results for others with honest behaviour. Ivanovic and Collins (2006) explain that performance is related to attitudes and work outcomes. Shield (2007) explains that there are two pivotal things in the concept of performance, subjectivity and relevance. Meanwhile, Armstrong (2009) explains that performance is related to institutional value and states that the idea of performance is multi-dimensional.

The lecturers' performance refers to the 'tridarma perguruan tinggi' (Three pillars of Higher Education) comprising education, research and community service. Okoro (2013) views the importance of knowledge stem from the lecturer research. Fitzmaurice (2013) states that the basis of lecturer's actions who is active in research are value, virtue, individual trust, joy, satisfaction in carrying out research. Research is an innovative thought that results in the publication of articles in various leading journals or patent registrations (Hedjazi \& Behravan, 2011).

\section{THEORETICAL FOUNDATION \& HYPOTHESIS DEVELOPMENT}

Individual characteristics and external conditions determine a person's work behaviour. Personal characteristics differences are considered as important factors that determine work behaviour including individual resources such as commitment both normative ethical, affection and continuance commitment.

Commitment becomes very important if it is associated with the functionalization of individuals in organizations aimed at ensuring the sustainability of organizational performance. Chen and Francesco (2003) found the relationship between commitment and employee performance. Affective commitment (AC) is positively related to performance, while continuous commitment $(\mathrm{CC})$ is not associated with performance. In addition, normative commitment (NC) moderates the relationship between performance and AC. The linear relationship between AC and performance is stronger for those who have lower NC. Khunsoonthornkit and Panjakajornsak (2018) assert that commitment is important to improve the research performance of institutions.

Individual sources are needed to involve someone in their work. Work engagement is described by carrying out its work role, working and expressing itself physically, cognitively and emotionally while working. Meyer and Maltin (2010) explained that affective commitment is related to work conditions that support work needs. Continuance Commitment (CC) has a positive reciprocal relationship with controlled regulations. Normative Commitment is positively related to ethics. Beukes and Botha (2013) suggested that there is a relationship between commitment and work engagement. The more committed someone is, the higher their involvement in their work.

Shaw (2003) explained that organizational commitment is a significant predictor of overall performance and helps with a dissonance perspective. Luque, Marin-Garcia, and Medina-Lopez (2015) which explain the influence of 
commitment to organizational performance. Pa'wan and Omar (2018) show the position of organizational commitment in relation to the achievement of higher education. Meyer and Maltin (2010) illustrate that employees as consumptive subjects include consuming value. The lecturer's bond to his work determines their activities concerning the implementation of Tridharma Perguruan Tinggi. The bond, either caused by the lecturer's value, interest in the world of research, and the moral responsibility on theoretical and practical problems, will determine their work engagement, including research activities. Lecturers who are interested in research have different productivity compared to lecturers who are not interested in research. A Work that contains involvement, or even drift, will result in optimal performance. The psychological conditions of both work engagement and efforts to break away are seen as rational psychological experiences mediated by individual perceptions to create conditions where they are personally involved and break away from work. Mental representation of work and its environment involve a person both in affective, cognitive and psychomotor. One's personal, work, and contextual experience implicitly determine their work output. Bakker and Albrecht (2018) put forward the work engagement position for organizational, group and individual outcomes. The strong dedication on the job showed better performance (Christian, Garza, \& Slaughter, 2011). Guan and Frenkel (2018) put the work engagement as a predictor of performance.

Based on the theoretical foundations above, commitment and work engagement are factors that influence lecturers' research performance. To illustrate the construction of thinking in this study, researchers used the framework as shown in Figure 1 as follows:

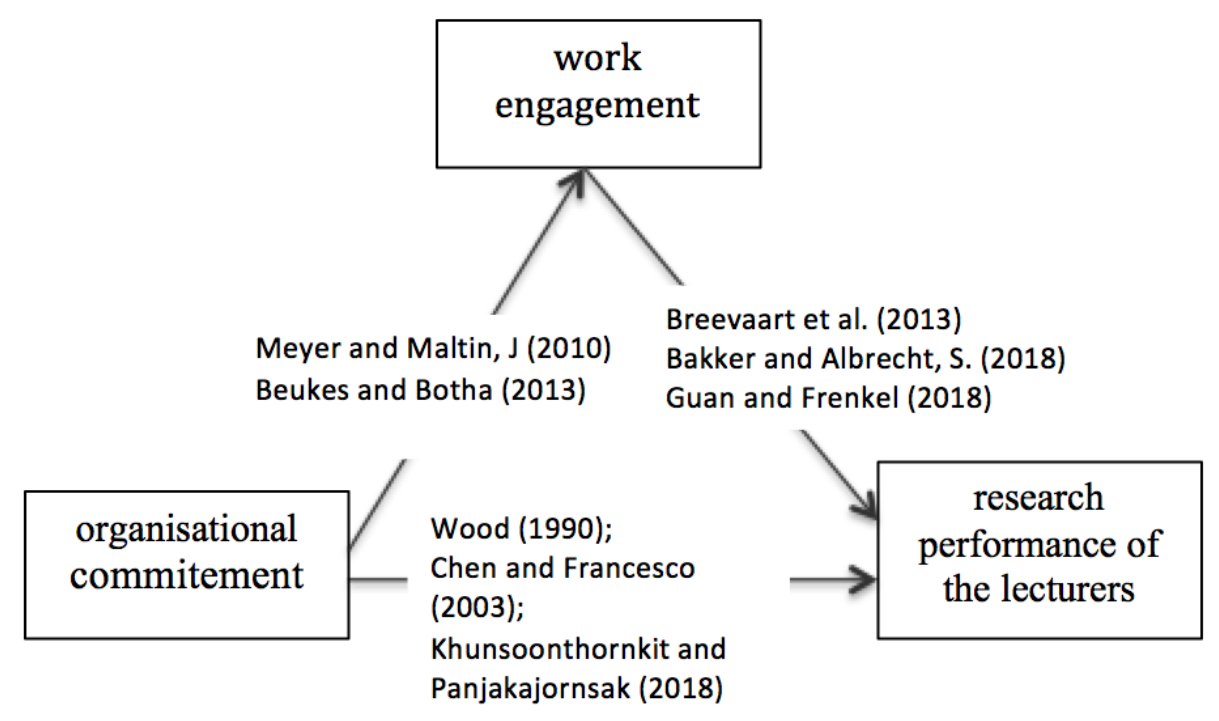

Figure 1. Conceptual Framework

The conceptual framework as depicted in Figure 1 produces a research paradigm proposition that illustrates the relationship between variables in this study. The relationship between variables of commitment, work engagement and research performance are shown in Figure 2 as follows: 


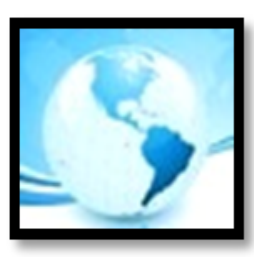

(MOJEM)

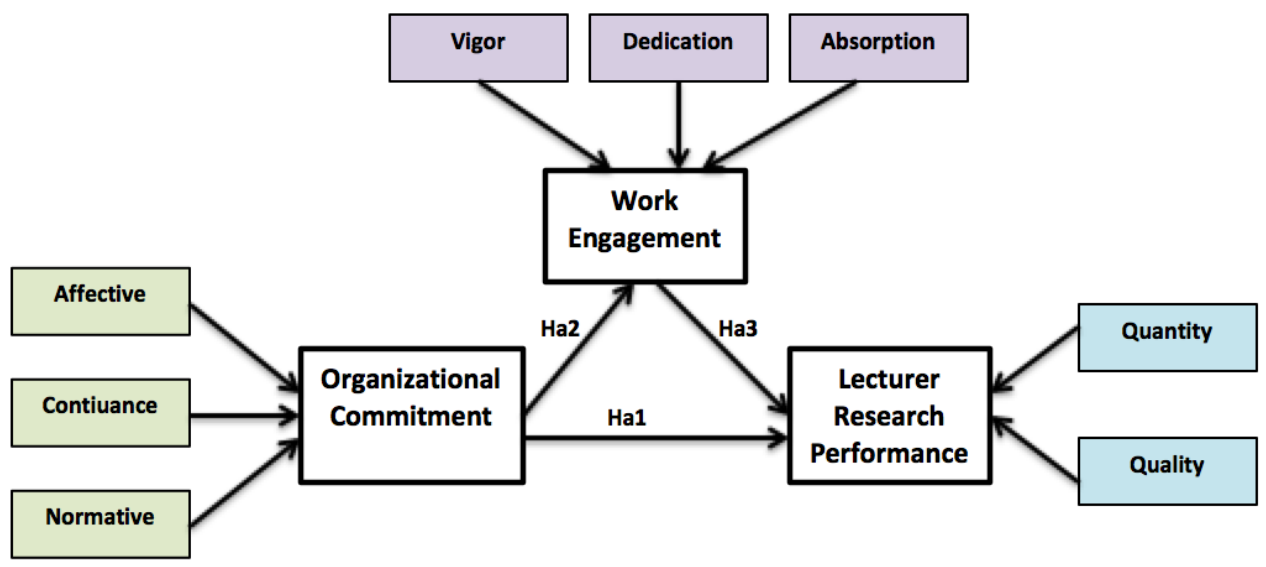

Figure 2. Research Paradigm

Based on conceptual framework and research paradigm, the hypotheses of this study are as follows:

$\mathrm{H}_{1}$ : Lecturer's commitment affects their research performance

$\mathrm{H}_{2}$ : Lecturer's commitment affects their work engagement

$\mathrm{H}_{3}$ : Lecturer's work engagement affects their research performance

\section{RESEARCH METHODS}

\section{Research Design}

The research design used explanatory survey method, a survey that obtain clarity of the relationship of variables. The variables employed in this study are commitment, work engagement and research performance. The unit of analysis in this study are permanent lecturers in private universities. This study used a one shoot time scope with cross-section data type. Hypothesis testing using the technique of determining the average score which refers to the Likert scale. Structural Equation Modeling statistical tests was used in order to process the data in the study.

\section{Population \& Sampling}

The population in this study were permanent lecturers of private universities in the provinces of West Java and Banten with the total of 22,480 . Determination of sample data is taken based on the adequacy of the sample using a SEM model that refers to the opinion that the number of samples refers to the number of indicator variables studied (Hair, Black, Babin, \& Anderson, 2014). Following the statement of Hair et al. (2014), a total of 388 samples were randomly selected from the population.

\section{Instrument}

Questionnaire was employed as the main research instrument used to collect research data. It was done by compiling a set of questions based on operational variables. Each variable in this study was tested for its validity and reliability. The questionnaire was prepared using a Likert scale. Likert scale is used due to its simplicity; besides, it is capable of describing attitudes, opinions, and perceptions of respondents' answers. Grading scale uses a scale value scale. The rating scale used a number that is easy to use for each item that is 5.4,3,2,1 with the following meanings:

$5=$ very good / very high / always

4 = good / high / often / rather high 
$3=$ normal / sufficient $/$ sometimes

2 = not good $/$ low $/$ rare

1 = not very good / very low / never

The measurement of commitment used the dimension proposed by Meyer and Allen (1993) as a resource for work. Measuring work engagement using the self-report questionnaire - the Utrecht Work Engagement Scale (UWES) - covers three dimensions namely vigour, dedication and absorption (Schaufeli et al., 2006). Bakker and Albrecht (2018) work engagement refers to the level of enthusiasm, dedication and absorption. Albercht et al. (2018) measure with statement: (1) feeling strong in work, (2) enthusiastic, (3) my work inspires me, (4) feels like working. Performance is measured by the number of journals published and the quality of the research for a certain period of time (Hedjazi \& Behravan, 2011). Harris and Kaine (1994) suggested that individual productivity in research is measured by the publication index produced, preferences and perceptions about issues related to research.

\section{Validity \& Reliability}

To test the validity of research instruments, Pearson product-moment correlation coefficient formula was employed. The purpose of validity test was to describe whether the research instrument is able to measure what should be measured. To get the validity value, the researcher correlated the item score with the total item. If there are items that do not meet the requirements, then these items will not be further investigated. These requirements must meet the following criteria:

a. If pearson correlation I $>0.30$, then the items are declared valid.

b. If pearson correlatill $\leq 0.30$, then these items are declared invalid. (Sugiyono, 2010)

The validity test results are shown in Table 1, Table 2 and Table 3 as follows.

Table 1.

Validity Test Results: Commitment

\section{Correlations}

\begin{tabular}{llrrrr}
\hline & & Affective & Continuance & Normative & Total Commitment \\
\hline \multirow{2}{*}{ Affective } & Pearson Correlation & 1 & $.903^{* *}$ & $.924^{* *}$ & $.967^{* *}$ \\
& Sig. (2-tailed) & & .000 & .000 & .000 \\
Continuance & $\mathrm{N}$ & 203 & 203 & 203 & 201 \\
& Pearson Correlation & $.903^{* *}$ & 1 & $.931^{* *}$ & $.971^{* *}$ \\
& Sig. (2-tailed) & .000 & & .000 & .000 \\
\multirow{3}{*}{ Normative } & $\mathrm{N}$ & 203 & 203 & 203 & 201 \\
& Pearson Correlation & $.924^{* *}$ & $.931^{* *}$ & 1 & $.979^{* *}$ \\
& Sig. (2-tailed) & .000 & .000 & & .000 \\
Total Commitment & $\mathrm{N}$ & 203 & 203 & 203 & 201 \\
& Pearson Correlation & $.967^{* *}$ & $.971^{* *}$ & $.979^{* *}$ & 1 \\
& Sig. (2-tailed) & .000 & .000 & .000 & \\
& $\mathrm{~N}$ & 201 & 201 & 201 & 201 \\
\hline
\end{tabular}

**. Correlation is significant at the 0.01 level (2-tailed). 


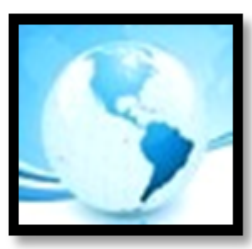

Based on Table 1 that Pearson Correlation value $\geq 0.30$, then the instrument commitment variables declared valid.

Table 2

Validity Test Results: Work Engagement

\begin{tabular}{|c|c|c|c|c|c|}
\hline \multicolumn{6}{|c|}{ Correlations } \\
\hline & & & & & Total Work \\
\hline & & Vigor & Dedication & Absorption & Engagement \\
\hline \multirow[t]{3}{*}{ Vigor } & Pearson Correlation & 1 & $.750^{* *}$ & $.209^{* *}$ & $.843^{* *}$ \\
\hline & Sig. (2-tailed) & & .000 & .003 & .000 \\
\hline & $\mathbf{N}$ & 203 & 203 & 201 & 201 \\
\hline \multirow[t]{3}{*}{ Dedication } & Pearson Correlation & $.750^{* *}$ & 1 & $.231^{* *}$ & $.853^{* *}$ \\
\hline & Sig. (2-tailed) & .000 & & .001 & .000 \\
\hline & $\mathrm{N}$ & 203 & 203 & 201 & 201 \\
\hline \multirow[t]{3}{*}{ Absorption } & Pearson Correlation & $.209^{* *}$ & $.231^{* *}$ & 1 & $.621^{* *}$ \\
\hline & Sig. (2-tailed) & .003 & .001 & & .000 \\
\hline & $\mathbf{N}$ & 201 & 201 & 201 & 201 \\
\hline Total Work & Pearson Correlation & $.843^{* *}$ & $.853^{* *}$ & $.621^{* *}$ & 1 \\
\hline \multirow[t]{2}{*}{ Engagement } & Sig. (2-tailed) & .000 & .000 & .000 & \\
\hline & $\mathrm{N}$ & 201 & 201 & 201 & 201 \\
\hline
\end{tabular}

**. Correlation is significant at the 0.01 level (2-tailed).

Based on Table 2, the Pearson Correlation value $\geq 0.30$, then the instrument work engagement variables has been declared valid.

Table 3

Validity Test Results: Performance

\begin{tabular}{llrrr}
\hline & \multicolumn{3}{c}{ Correlations } \\
\hline Quntity & Quantity & Quality & Total Performance \\
& Pearson Correlation & 1 & $.609^{* *}$ & $.878^{* *}$ \\
& Sig. (2-tailed) & & .000 & .000 \\
Quality & $\mathrm{N}$ & 203 & 203 & 201 \\
& Pearson Correlation & $.609^{* *}$ & 1 & $.908^{* *}$ \\
& Sig. (2-tailed) & .000 & .000 \\
Total & $\mathrm{N}$ & 203 & 203 & 201 \\
Performance & Pearson Correlation & $.878^{* *}$ & $.908^{* *}$ & 1 \\
& Sig. (2-tailed) & .000 & .000 & 201 \\
\hline
\end{tabular}

**. Correlation is significant at the 0.01 level (2-tailed). 
Based on Table 3, the Pearson Correlation value is $\geq 0.30$, then the instrument performance variables has been declared as valid.

Data collection procedure was done by visiting lecturers directly with the help of a team in charge of distributing questionnaires for 2 weeks and filling in time for 1 week. In addition to directly distribute questionnaires, data collection research is also done by using Google Docs.

To test the reliability of research instruments, Cronbach alpha coefficient $(\alpha)$ was employed. To this end, the following criteria were applied:

a. The research instrument is considered reliable if the obtained alpha coefficient $(\alpha) \geq 0.6$.

b. The research instrument is considered not reliable if the obtained alpha coefficient $(\alpha)<0.6$.

Table 4

Reliability Test Result

\begin{tabular}{lrr}
\hline & Cronbach's Apha & N of Items \\
\hline Commitment & 0.971 & 3 \\
Work Engagement & 0.662 & 3 \\
Performance & 0.752 & 2 \\
\hline
\end{tabular}

Based on Table 4, it can be seen that the reliability coefficient for each variable is greater than 0.60 . These results indicate that all items of research instrument statements are reliable. Accordingly, they can be used to measure the variables under study.

\section{FINDINGS AND DISCUSSION}

\section{Demographic Information of Respondents}

The demographic characteristics of lecturers are quite varied. $58.8 \%$ of them are male. There are still lecturers with an undergraduate equivalent of $13.3 \%$ with additional certificates of expertise and practical experience. $56.2 \%$ of graduates are Master's degree while 7\% of them hold doctoral degrees. In general, their lecturing experience ranged from 11 to 20 years. Respondent information are shown in Table 5 as follows: 


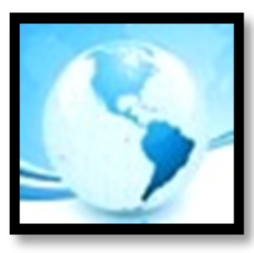

MALAYSIAN ONLINE JOURNAL OF

EDUCATIONAL MANAGEMENT

(MOJEM)

Table 5

The Demographic Information of Respondents

\begin{tabular}{llrr}
\hline Demographic Variables & Classifications & Frequency & Percent (\%) \\
\hline Age & Below 30 years & 4 & 1.00 \\
& $31-45$ years & 55 & 14.20 \\
& $46-55$ years & 315 & 81.20 \\
& 56 years and above & 14 & 3.60 \\
Gender & Male & 228 & 58.80 \\
& Female & 160 & 41.20 \\
Highest Qualification & Diploma 4 & 52 & 13.30 \\
& Bechelor degree & 91 & 23.50 \\
& Master's degree & 218 & 56.20 \\
& Doctoral degree & 27 & 7.00 \\
& & & \\
Experience as Lecturer & Less than 5 years & 8 & 2.00 \\
& 6 years - 10 years & 55 & 14.20 \\
& 11 years - 20 years & 311 & 80.20 \\
& More than 21 years & 14 & 3.60 \\
& & & \\
Position & Lecturer & 44 & 11.40 \\
& Senior Lecturer & 274 & 70.60 \\
& Assoc. professor & 47 & 12.20 \\
& Professor & 23 & 5.80 \\
\hline
\end{tabular}

Descriptive analysis results show that lecturers with research experience over 10 years are $83.6 \%$. The highest qualification and experience following a number of scientific publications writing training affect the quality of research results. Experience directing the actions of the faculty to realize the practical value of knowledge as included in research activities. Qualification affects the ability to conduct research, especially the ability concerning research methodology.

\section{Measurement Weighting Factor}

Results of further testing are the outer models. Based on the results of the test, it is known that the weight of the factors of each indicator variable is accepted. According to Chin (1998), the weight value of the factor is above 0.4. The Average Variance Extracted value of each variable can reflect latent variables. The variable composite reliability value is greater than the recommended value of 0.70 . This value indicates that indicators have consistency in measuring latent variables. Value weighting factors indicate that the indicator for the variable commitment received. Value weighting factor for continuance commitment (0.96), affective commitment (0.93), normative commitment (0.81). The weighting factor value for enthusiasm (0.81) is dedication (0.79) and absorption (0.81). For indexed publication indicator indicators, the value of the factor weight is 1 and the issue of reference frequency (0.94). The results are in accordance with Meyer and Allen (1993) for the commitment variable. Research results for work engagement variables, according to Schaufeli et al. (2006), Ghorbannejad and Esakhani (2016) and Bakker et al. (2018). The findings on performance indicator in this study is consistent with the finding obtained by Hedjazi and Behravan (2011).

The structural model test results are as follows: $\mathrm{CMIN} / \mathrm{DF}=2.537, \mathrm{GFI}=0.990, \mathrm{TLI}=0.993, \mathrm{CFI}=0.996$ the RMSEA value is 0.039 . Overall, the test results show that the value obtained concludes that the proposed model is fit. The 
PNFI value is 0.603 greater than the recommended value. Some criteria as fit models are met. Therefore, the modification of the model is not carried out to explain the reality.

The CR value (critical ratio) obtained was 8.834 (greater than 1.96), meaning that there is a significant effect of work engagement on performance. This value can be used as a reference for parameters for model universality. CR Value Effect of commitment to 3,593 or significant performance. While work engagement on performance is significant with the value of CR 11.001.

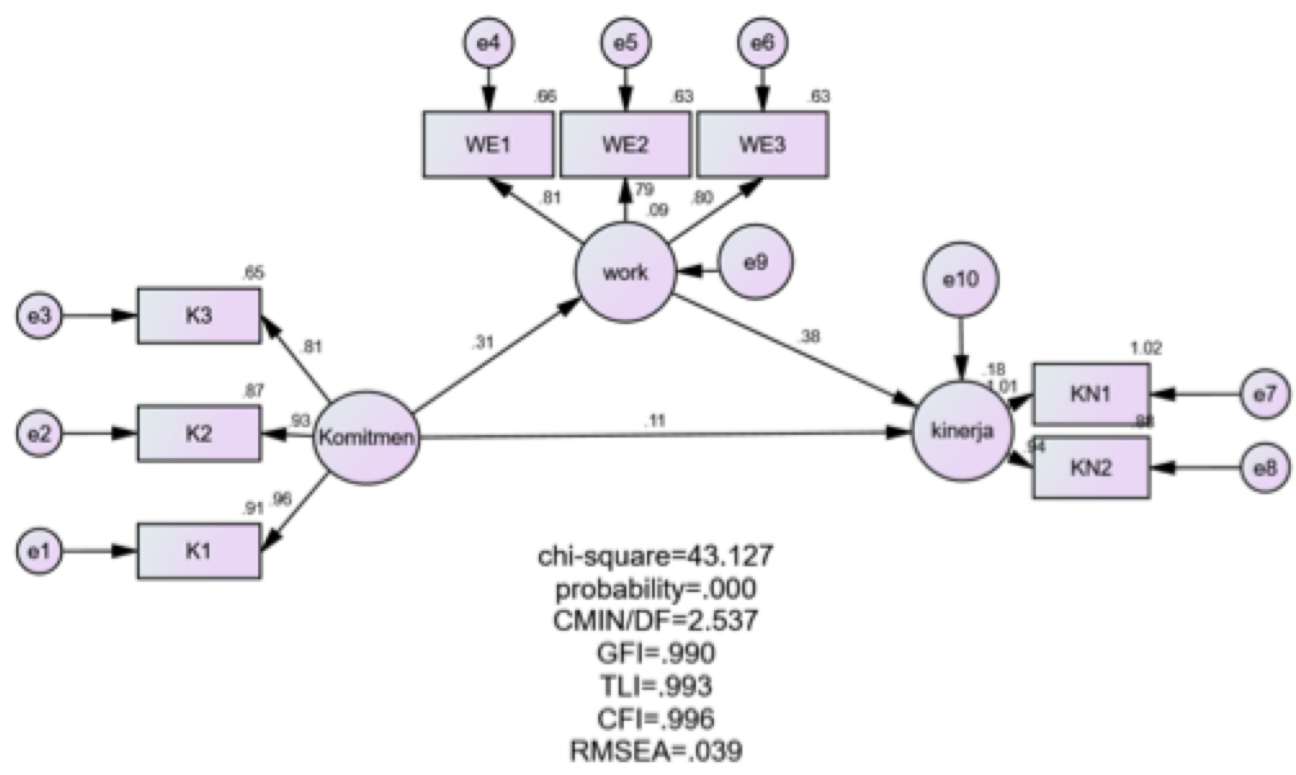

Figure 3. Verification Test Results

T

he estimated value of the effect of the level of organizational commitment on the level of work engagement is 0.31. This means that the hypothesis stating the commitment affect work engagement is accepted. A person who has a sense of attachment based on values, interests and norms becomes more competent, which means being swept away in his work as a researcher. Estimated value of Effect Level of commitment to performance is 0.38 , indicating that changes in research performance can be explained by a commitment level of $38 \%$, with 0.00 significance value means hypothesis is accepted or Ho is rejected.

Based on the $5 \%$ error rate, the hypothesis stating the level of commitment positively affect research performance is accepted. Commitment directly affects the performance by $11 \%$. The total effect is as follows:

Table 6

Statistical Test Results

\begin{tabular}{l|rrr}
\hline & Commitment & Work & Performance \\
\hline Work & .246 & .000 & .000 \\
Performance & .164 & .341 & .000 \\
\hline
\end{tabular}




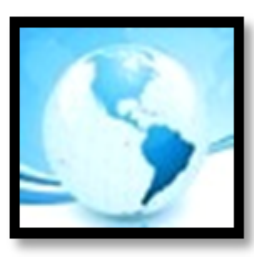

\section{MALAYSIAN ONLINE JOURNAL OF EDUCATIONAL MANAGEMENT (MOJEM)}

The total effect of commitments on work engagement is $24.6 \%$. Total effect of commitment on performance $16.4 \%$. The effect of work engagement on performance is $34.1 \%$, this is in line with Breevaart, Bakker, Demerouti, and VandenHeuvel (2015).

Commitment drives performance. This refers to the concept proposed by Meyer and Allen (1993) regarding commitment, the conditions of organizational commitment of lecturers both affective, normative and continuance need to be improved in order to sustain the organizational success in carrying out its functions. Normative commitment grows because of the moral values that are in line with morality (Alhawary \& Aboruman, 2011). Moreover, it is understood that in the epistemology of science, there are problems related to morals. Conformity between individuals' moral and organizations encourages individual commitment in research. Research is a part of the process for understanding ethical issues for both the organization and for individuals. Luque et al. (2015) show that employee's commitment contributes to increased internal integration, and internal integration affects performance both directly and indirectly. Chen and Francesco (2003) explain the relationship of commitment and employee performance. This is in line with Anat and Carmeli (2003) who stated that affective organizational commitment connects workers with organizational goals. The higher the commitment, the higher the work engagement. The study is in line with Beukes and Botha (2013) which suggests the effect of commitment on work engagement

In line with Allen and Meyer (1993), the commitment dimension is continuance and exchange between the owner of the organization and its members as a source for work engagement. Lecturers need some support in the form of material for sustainability commitments, interests in research objects including methodological issues. Ethical commitment is necessary that the lecturers examine the results of research that contributes to the changes.

The results of the study showcase how the position of the lecturer is very strategic in college. Furlong and Cartmel (2009) emphasize commitment as something fundamental to higher education. Efforts to solve the lack of lecturers' commitment in Private Universities are part of a process that involves functions within the organization including its leaders and systems. Research on the effect of commitment on work engagement is still scarce. Commitment is generally placed as a variable that is influenced by work engagement. In this study, commitment is a predictor for work engagement.

Work engagement as a predictor of research performance is in line with Bakker and Albrecht (2018) who confirms the work engagement function for organizations. The results of the study are in line with Christian et al. (2011). Therefore, there is a need for management to maintain a HR system that encourages employee involvement commitment and work engagement function to improve performance, which was considered very low. This is counterproductive to the demand that lecturers can produce research that shows the existence of business phenomena, research gaps and the resulting theoretical gaps. The research of private university lecturers should focused towards science-based to solve these problems, especially problems of theory and empirical phenomena. Universities face high scientific needs to solve problems in society. This is supported by Johnstone, D'Ambrosio, and Yakoboski (2010) who argued universities face challenges from a new knowledge-based global society. Higher education must rediscover itself and rethink their roles and goals.

The obstacles in building the performance of lecturers through the system are the lack of steps in realizing the expected performance. The design of performance management is theoretically outstanding but difficult to operate to build commitment including the value of the questions obtained by the lecturer. HR policies and practices for high and strategic performance are still weak. The implementation or expansion of the HighPerformance Work System (HPWS) for lecturers is not supported by adequate consistency and organizational commitment.

The design of a system that supports the research performance of lecturers in universities is not released from the interest and "drift" of lecturers in research. Research does not only require driving interest. Lecturers, as agents of 


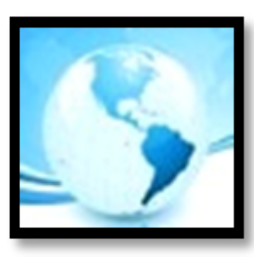

\section{MALAYSIAN ONLINE JOURNAL OF EDUCATIONAL MANAGEMENT (MOJEM)}

science, are required to show intellectual virtue through their research. Traditions in research do not only focus on research results as output that are functional and theoretical. The tendency to expand access to knowledge is a manifestation of the ethical and social awareness of researchers. The research for a lecturer is a social movement to claim the position as a subject of knowledge that is not isolated, it can be trusted that both mind, senses and contents of the mind are contained in the writing.

Based on the above discussion, some important findings are obtained. Three dimensions to measure organizational commitment are at a moderate level except the continuance dimension. This shows that lecturers are committed based on their interests and norm values. Material value is not an indicator of lecturer commitment. Referring to the concept proposed by Meyer and Allen (1993) that the commitment of lecturers, both affective, normative and continuance, still lacks the success of an organization in carrying out its functions.

The lecturer's weak commitment in the private university can be solved by optimizing the changing factors. Their commitment will determine the continuity of the functions of higher education institutions since they are part of the functions of higher education and have a very strategic position. Lecturers with low organizational commitment are important issues for universities to solve. The successful implementation of research, the use of technology and higher education services is determined by the support and lecturers' commitment. The effort to solve the problem of the lack of lecturer commitment is part of a process that involves functions within the organization including the leadership and the existing system at the university. These efforts need structural and cultural support (work culture). These two factors will encourage an increase in lecturers' commitment.

Work engagement, as a mediating variable, is the main predictor to improve the research performance of lecturers. The test results show that commitment is the key to improve the research performance of lecturers. The responsibilities of lecturers in research cannot be fulfilled without organizational support. Therefore, the commitment and work engagement of lecturers in research is an important focus in the human resource management system in higher education. Organizations need to encourage lecturer's understanding of commitment and work engagement to improve research performance as part of continuous improvement efforts.

\section{RECOMMENDATIONS}

The research highlighted the need to optimize organizational functions that focus on efforts to improve the lecturers' commitment and work engagement so that research performance improvement can be achieved. Lecturer's high research performance will be able to enhance the reputation of higher education institutions.

The recommendations given based on the results of this study for Higher Education Service Institutions is that improving the quality of higher education cannot be separated from the guidance of lecturers, especially those related to research. The Government through the Higher Education Service Institution is expected to continue to increase support in the form of policy making that encourages program optimization that leads to increased commitment and work engagement of lecturers to research through policy research budget allocation and increase training activities in writing scientific articles for lecturers.

For future studies, research can be conducted to measure the lecturer's level of research performance in broader research objects that do not establish the status of state or private tertiary institutions and their impact on the lecturers' competitiveness. It is expected that the research can answer the question on lecturers' research influence on the improvement of their competitiveness. The results of this research are expected to be a reference for the government in developing the direction and policy of national research development. 


\section{CONCLUSION}

Performance is influenced by work engagement based on commitment to the ethical awareness of the function of lecturers in higher education. Work engagement mediates the effect of commitment on research performance partially. The influence becomes stronger with the mediation of work engagement. This shows that work engagement as part of the organization can improve lecturers' research performance. The better the work engagement, the higher the research performance achieved.

Managerial implication that lecturers' research performance is low is a general condition due to low work engagement. A fundamental paradigm shift is needed in managing lecturer performance to improve lecturers' research performance. The results of this study as a framework for building a metamodel to encourage improvement in lecturers' research performance through commitment and work engagement factors as the focus of attention.

The limitations of the study are the existence of uncontrolled variables namely private universities' ranking and research budget allocation. The lecturers investigated in this study consisted of private University lecturers without distinguishing experience in research with a variety of epistemology choices.

\section{REFERENCES}

Adewale, A. S., Ghavifekr, S., \& Megat Daud, M. A. K. (2018). Leadership and staff organizational citizenship behaviour in higher education institutions: A quantitative analysis. Malaysian Online Journal of Educational Management, 6(1), 36-52.

Ahmad, H. H. (2014). An overview of the Malaysian higher education issues and challenges. Malaysian Online Journal of Educational Management, 2(1) 10-19.

Albrecht, S., Breidahl, E., \& Marty, Andrew (2018). Organizational resources, organizational engagement climate, and employee engagement, Career Development International, Emerald Insight. https:// doi.org/10.1108/CDI-04-2017-0064

Alhawary, F. A., \& Aboruman, A. H. (2011). Measuring the effect of academic satisfaction on multi-dimensional commitment: A case study of applied science private university in Jordan. International Business Research, $4(2), 153-160$.

AL-Sinawi, Saleh, H. N., Piaw, Chua, Yan, \& Idris, Abdul, Rahman. (2016). Developing a Model of Work Performance System and Institutional Performance for Strategic Human Resource Management in The Ministry of Education, Oman, Malaysian Online Journal of Education Management, 4(4), 1-16

Armstrong, M. (2009). Armstrong's handbook of performance manageme ${ }^{\text {nt }}$. (4th ed.). London: Kogan Page.

Anat, F., \& Carmeli, A. (2003). An empirical assessment: Reconstructed model for five universal forms of work commitment. Journal of Managerial Psychology, 18(7/8) 708-725.

Bakker, A. B., \& Albrecht, S. (2018). Work engagement: Current trends. Career development international. ResearchGate, 23(1), 4-11.

Bakker, A. B., Demerouti, E., \& Sanz-vergel, A. I. (2014). Burnout and work engagement: The JD - R approach. Annual Review of Organizational Psychology and Organizational Behavior, 1, 389-411. 


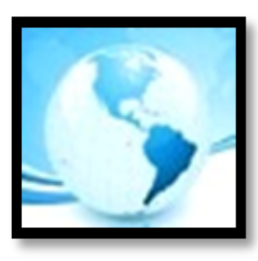

\section{MALAYSIAN ONLINE JOURNAL OF EDUCATIONAL MANAGEMENT (MOJEM)}

Bakker, A. B., \& Demerouti, E. (2018). Multiple levels in job demands-resources theory: Implications for employee well-being and performance. In E. Diener, S. Oishi, \& L. Tay (Eds.), Handbook of wellbeing. Salt Lake City, UT: DEF Publishers.

Baloyi, S., van Waveren,C., \& Chan,C,C. (2014). The Role Of Supervisor Support In Predicting Employee Job Satisfaction From Their Perception Of The Performance Management System: A Test Of Competing Models In Engineering Environments. South African Journal of Industrial Engineering 25(1), 85-9

Beukes, I., \& Botha, E. (2013). Organisational commitment, work engagement and meaning of work of nursing staff in hospitals. SA Journal of Industrial Psychology, 39(2), 10. http://dx.doi.org/10.4102/ sajip.v39i2.1144

Breevaart, K., Bakker, A. B., Demerouti, E., \& VandenHeuvel, M. (2015). Leader-member exchange, work engagement, and job performance. Journal of Managerial Psychology, 30(7), $754-770$.

Cerasoli, C. P., Nicklin, J. M., \& Ford, M. T. (2014). Intrinsic motivation and extrinsic incentives jointly predict performance: A 40-Year meta-analysis. Psychological Bulletin, 140(4), 980-1008.

Chen, C. Y. (2015). A study showing research has been valued over teaching in higher education. Journal of Vocational Behavior, 15(3), 15-32.

Chen, Z. X., \& Francesco, A. M. (2003). The relationship between the three components of commitment and employee performance in China. Journal of Vocational Behavior, 62(3), 490-510.

Chin, W. W. (1998). The partial least squares approach to structural equation modeling. New Jersey. Lawrence Erlbaum Associates.

Christian, M. S., Garza, A. S., \& Slaughter, J. E. (2011), Work engagement: A quantitative review a test of its relations with task and contextual performance, Personnel Psychology, 64(1), 89-136.

Deem, R., Hillyard, S., \& Reed, M. (2007). Knowledge, Higher Education, and the New Managerialism: The changing management of UK Universities. Oxford: Oxford University Press.

Edgar, F., \& Geare, A. (2013). Factors influencing university research performance. Studies in Higher Education, 38(5), 774-792. doi:10.1080/03075079.2011.601811

Firat, B. O., Mul, S. D., \& Wichelen, S. V. (2009). Commitment and complicity in cultural theory and practice. London: Columbia University Press.

Fitzmaurice, M. (2013). Constructing professional identity as a new academic: A moral endeavor. Journal Studies in Higher Education, 38(4), 613-622.

Furlong, A., \& Cartmel, F. (2009). Higher education and social justice. NY: Open University Press.

Ganieva, Y. N., Sayfutdinova, G. B., Yunusova, A. B., Sadovaya, V. V., \& Neile, K. (2015). Structure and content of higher professional school lecturer education competence. Review of European Studies, 7(4), 32-39. 


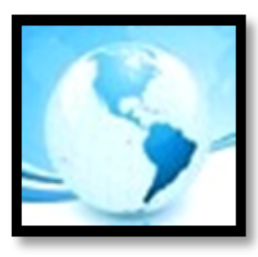

Ghasemy, M., Hussin, S., Daud, M. K. M. M., \& Nor, M. M. (2015). Assessment of leadership performance effectiveness in higher education: A Malaysian perspective. Malaysian Online Journal of Educational Management, 3(4) $63-79$.

Ghavifekr, S., Afshari, M., Siraj, S., Zabidi, A., \& Razak, A. (2013). Managing change in educational organization: A conceptual overview. Malaysian Online Journal of Educational Management, 1(1), 1-13.

Ghorbannejad, P., \& Esakhani, A. (2016). Capacity to engage: studying role of individual differences in work engagement - evidences from Iran. Journal of Management Development, 35(9), 1174-1183.

Gigch, J. P. V. (1996). The design of an epistemology for the management discipline which resolves dilemmas among ethical and other imperatives. Systems Practice, 10(4), 381-394.

Goldman, A. I. (1999). Knowledge in a social world. Oxford: Oxford University Press.

Griffioen, D. (2018). Building research capacity in new universities during times of academic drift: Lecturers' professional profiles. Higher Education Policy, 2018, 1 - 20. doi: 10.1057/s41307-018-0091-y

Guan, X., \& Frenkel, S. (2018). How HR practice, work engagement and job crafting influence employee performance. Chinese Management Studies, 12(3), 591-607.

Hair, J., Black, W., Babin, B., \& Anderson, R. (2014). Multivariate data analysis. USA: Pearson New International Education.

Harris, G., \& Kaine, G. (1994). The determinants of research performance: A study of Australian university economists. Higher Education, 27(2), 191-201. doi:10.1007/bf01384088

Hedjazi, Y., \& Behravan, J. (2011). Factors influencing research productivity of agriculture faculty members in Iran. Higher Education, 62(5), 635-647. doi:10.1007/s10734-011-9410-6.

Ivanovic, A., \& Collins, P. H. (2006). Dictionary of Human Resources and Personnel Management (3th ed.). London: A and $C$ Black.

Johnstone, D. B., D’Ambrosio, M. B., \& Yakoboski, P. (2010). Higher education in a global society. UK: Edward Elgar Pub. doi:10.4337/9781849805315.

Kahn, W. A. (1990). Psychological conditions of personal engagement and disengagement at work. Academy of Management Journal, 33, 692-724.

Khalid, H. (2016). Higher education volume and value of output: Experimental calculations for Malaysia. Malaysian Online Journal of Educational Management, 4(4), 17-36.

Khunsoonthornkit, A., \& Panjakajornsak, V. (2018). Structural equation model to assess the impact of learning organization and commitment on the performance of research organizations. Kasetsart Journal of Social Sciences, 39(2018), 457-462.

Kumar, R. K., \& Eng, K. G. (2012). Perceived organizational commitment and its impact to the turnover intention: A correlation analysis. Journal of Global Business and Economics, 4(1), 40-57. 


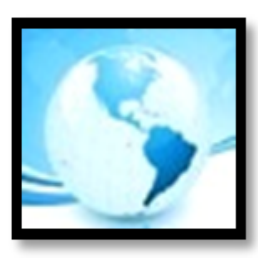

\section{MALAYSIAN ONLINE JOURNAL OF EDUCATIONAL MANAGEMENT (MOJEM)}

Leiter, M. P., \& Bakker, A. B. (2010). Work engagement: A handbook of essential theory and research. London. Psychology Press.

Loughlin, M. (2004). Management, science and reality. Philosophy of Management, 4(2), 36-44.

Lucki, E. O. I., \& Yusoff, N. B. N. (2013). A conceptual framework on teaching qualifications, Characteristics, competence and lecturer performance for higher education institutions in Nigeria. Malaysian Online Journal of Educational Management, 1(3), 35-47.

Luque, A. R., Marin-Garcia, J. A., \& Medina-Lopez, C. (2015). An analysis of the direct and mediated effects of employee commitment and supply chain integration on organizational performance. International Journal of Production Economics, 162, 242-257.

Meyer, J. P., \& Allen, N. J. (1993). Organizational commitment: Evidence of career stage effects. Journal of Business Research, 26(1), 49-61.

Meyer, J. P., \& Maltin, E. R. (2010). Employee commitment and well-being: A critical review, theoretical framework and research agenda. Journal of Vocational Behavior, 77(2), 323-337.

Moser, P. K. (2002). The Oxford Handbook of Epistemology Oxford. UK: Oxford University Press.

Nguyen, T. L. H. (2015). Building human resources management capacity for university research: The case at four leading Vietnamese universities. Higher Education, 71(2), 231-251.

Okoro, J. (2013). Lecturers' perception of strategies for enhancing business education research in tertiary institutions in Nigeria. Journal of Education and Learning, 2(4), 102-112.

Pa'wan, F., \& Omar, R. (2018). Effects of innovative organizational climate on organizational commitment in Malaysian higher. Malaysian Online Journal of Educational Management, 6(2), 1-21.

Pfeffer, J., \& Langton, N. (1993). Wage inequality and the organization of work: The case of academic departments. Administrative Science Quarterly, 33(4), 588-606.

Poff, R. A. (2001). Understanding the relationships between involvement, commitment, and future behaviour intentions of Kayakers and canoeists using structural equation modeling. (Unpublished doctoral dissertation). Indiana University, USA.

Rakhmatullin, R., \& Brennan, L. (2013). Motivation behind researchers' participation in formal networking research projects funded by the European Union. Journal of the Knowledge Economy, 5(2), 305-329.

Rasmussen, D. C. (2016). Adam Smith on What Is Wrong with Economic Inequality. American Political Science Review, 110(2), 342-352. doi:10.1017/S0003055416000113

Robbins, S., \& Judge, T. A. (2017). Organizational behaviour ( $7^{\text {th }}$ ed.). NY: Pearson.

Schaufeli, W. B., \& Bakker, A. B. (2004). Job demands, job resources, and their relationship with burnout and engagement: A multi-sample study. Journal of Organizational Behavior, 25(3), 293-315. 


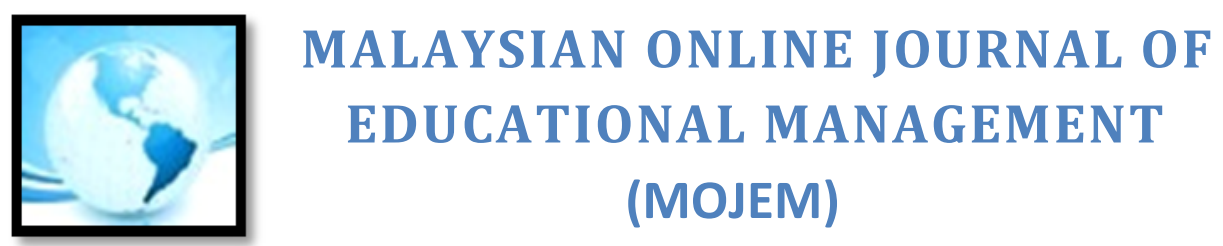

Schaufeli, Wilmar, B., Bakker, Arnold, B., \& Salanova, Marisa. (2006). The Measurement of Work Engagement with a Short Questionnaire: A Cross-National Study. Educational and Psychological Measurement Journal, 66(4), 701-716

Shaw, P. (2003). Changing conversations in organizations a complexity approach to change. London: Routledge.

Shield, J. (2007). Managing employee performance and reward. NY: Cambridge University Press.

Sihotang, K. (2016). Human philosophy. Yogyakarta: Kanisius.

Sugiyono, S. (2010). Metode Penelitian Pendidikan Pendekatan Kuantitatif, kualitatif, dan R\&D. [Method of evaluating quantitative, qualitative and R\&D education approaches]. Education Bandung: Alfabeta.

Sukirno, D. S., \& Siengthai, S. (2011). Does participative decision-making affect lecturer performance in higher education. International Journal of Educational Management, 25(5), 494-508.

Ulrich, D. (1998). Human resources champion. USA: Harvard Business School Press.

Wood, F. (1990). Factors influencing research performance of university academic staff. Higher Education, 19(1), 81-100. 